\title{
News Briefs and Reports
}

\section{Developments}

\section{GROUND BROKEN FOR NBS COLD \\ NEUTRON RESEARCH FACILITY}

Ground was broken at NBS on November 20 for the construction of one of the few cold neutron research facilities in the world. The new laboratory will make cold neutron research easily available to U.S. scientists working in such fields as materials science, chemistry, and biology.

Typical areas of application include the design of high-temperature, high-strength ceramics for engines; the study of improved semiconductor devices; the development of new magnetic alloys for more efficient electric motors; the creation of new chemical catalysts; and the precise measurement of newly engineered biomolecules.

The $\$ 25$-million facility will be housed in a specially designed research hall to be built at the NBS research nuclear reactor. A recently installed "cold source" supplies the low-energy neutrons.

Initial instrumentation will include: a high-resolution small-angle neutron scattering (SANS) spectrometer, one of the fundamental tools of neutron analysis, and an instrument which will rank with the best of its kind in the world; the best neutron depth-profiling instrument in the world; and two temporary facilities, a second SANS instrument and time-of-flight spectrometer. Ultimately, the center will include 15 experimental stations; 10 will be instrumented and operated by NBS and five will be instrumented and operated by outside groups.

These outside groups, Participating Research Teams (PRTs), will come from industrial, academic, or government research institutions and will fully instrument and maintain their stations in return for exclusive use of two-thirds of the available research time. The high-resolution SANS spectrometer is being constructed by a PRT consisting of NBS and Exxon Research and Engineering.

An external advisory committee will be set up to handle the allocation of research time, which will be made available to all U.S. users. The first experimental stations should become available late in 1989.

For further information, contact Michael Rowe at the National Bureau of Standards, Gaithersburg, MD 20899.

\section{DETAILS NOW AVAILABLE ON SUPER- CONDUCTING CONTACTS}

The high resistance that usually occurs where external leads are attached to ceramic superconductors is an obstacle to both measurements and practical applications of the newly developed highcritical-temperature superconductors. Work by NBS and the Westinghouse Research and Development Center, Pittsburgh, Pennsylvania, has produced a new method for making low-resistance electrical contacts on ceramic superconductors.

The researchers developed the new method after noticing that there was a correlation between the ages of many superconductor samples and their contact resistivities. The new method involves three parts, which work together to produce low contact resistivity: minimizing the air exposure time minimizes the degradation of the superconductor surface that occurs before making the contacts; sputter etching the surface removes the degraded layer; and depositing a thin layer of a noble metal-silver and gold were used-protects the surface and minimizes further degradation of the superconductor surface.

When the method was tried on old samples exposed to air for over 2 months, the contact resistivity was about 10 times higher than that for 
contacts formed on fresh samples only an hour old. A deeper sputter etch may be necessary for superconductors having long exposure to air.

For the particular superconductor tested, bulk $\mathrm{YBa}_{2} \mathrm{Cu}_{3} \mathrm{O}_{7}$, the sample was etched to a depth of 20 to 50 nanometers at $1.25 \mathrm{kV} \mathrm{rms} \mathrm{in} \mathrm{3-Pa} \mathrm{argon} \mathrm{for}$ about 3 minutes. A 1- to 6-micrometer-thick contact pad was immediately sputtered onto the surface ( $4.2 \mathrm{kV}$ rms, no applied bias), also under an argon atmosphere. The superconductor temperature was held to less than $100^{\circ} \mathrm{C}$ with a watercooled sample holder.

For further information, contact: Jack Ekin, Electromagnetic Technology Division, National Bureau of Standards, Boulder, CO 80303, or call 303/497-5448.

\section{NBS TESTIFIES ON SUPERCONDUCTIVITY LEGISLATION}

On October 7, NBS Deputy Director Raymond Kammer testified before a joint meeting of two House subcommittees considering pending legislation on high-temperature superconductivity research.

Noting that much of the nation's expertise in superconductivity research lies in the national laboratories like NBS, Kammer said, "It is our belief that these technical resources and those of other federal laboratories should be made available to our private industry without exerting the degree of government control that appears to be typical in many other nations." Kammer opposed the creation of additional levels of management to oversee the government's superconductivity research.

\section{NEW ACOUSTIC TECHNIQUE PROMISES BETTER WAY TO EVALUATE INSTALLATION OF HOME THERMAL INSULATION}

NBS researchers are completing testing of a new measurement technique, based on acoustics, that shows considerable promise for quality control in the manufacture of insulation and could also be the basis for efficient, low-cost tools for evaluating loose-fill attic insulation after it is installed.

NBS researchers - funded by the Mineral Insulation Manufacturers Association, the U.S. Department of Energy, and NBS-have developed a high-speed method for indirectly measuring either the coverage or the R-value of certain types of loose-fill insulation by passing sound waves through a sample of material and measuring the sound insertion loss (i.e., the decrease in sound level) caused by the insulation at various frequencies.
In the laboratory system developed at NBS, pulses of sound containing energy in the frequency range of 2.5 to 25 kilohertz are projected through a sample of insulating material. The samples of insulation are contained in individual baskets which have acoustically transparent bottoms and are supported inside a specially designed test chamber.

The sound insertion loss of loose-fill insulations has been found, for a given insulating material, to correlate quite well with the coverage (mass per unit area) of the material, particularly for fiberglass materials. Predicting coverage of rock wool insulation is somewhat problematic, according to researchers, because of the presence of fused material (shot).

Researchers say that a version of the laboratory apparatus used at NBS could be useful to insulation manufacturers for quality control. The acoustic test apparatus collects and analyzes data in a few minutes and yields results that would require several hours to obtain using thermal measurement procedures. Moreover, they say, the principles could be applied to field instrumentation for characterizing insulation installed in attics by using acoustic probes either suspended over the insulation, or inserted into the insulation through holes bored in the ceiling. Two NBS researchers, Gerald V. Blessing and Daniel R. Flynn, recently were granted a patent for various design concepts for a field instrument utilizing these ideas.

The results of the NBS experiments have been presented to ASTM Committee C16 on Thermal Insulation, which is interested in the acoustic technique as a possible ASTM test method. In addition, ASTM has agreed to coordinate an effort to raise the funds needed to develop a practical field instrument based on acoustic measurements of installed loose-fill insulation.

For further information, contact Gerald Blessing, A147 Sound Building, National Bureau of Standards, Gaithersburg, MD 20899, or call 301/ 975-6627.

\section{NBS REPORTS TO CONGRESS ON STRUCTURAL DAMAGE IN RECENT CALIFORNIA QUAKE}

The biggest share of the structural damage from the October earthquake in California was sustained by older, unreinforced masonry buildings that were not designed to absorb an earthquake's energy or were not connected firmly to their foundations. That assessment was made by John W. Lyons, director of the NBS National Engineering Laboratory in testimony on November 10 before the U.S. House Subcommittee on Science, Research and Technology. 
Most of these observations reflect lessons already learned from previous quakes and research, said Lyons, but they are important because in many earthquake-susceptible parts of the country such structures are still being built.

In a report released at the hearings, $H$. $S$. Lew, head of the NBS structural evaluation program, also noted that light fixtures and suspended ceilings which were not properly secured fell during the earthquake. In addition, he said, walls with large windows provided little stiffness to the structure and, in many cases, window glass fractured into large pieces and fell on sidewalks.

Lew, who was in California when the quake struck, found only one highway bridge that sustained significant damage. Most bridges had been repaired or strengthened to increase their earthquake resistance after the 1971 San Fernando earthquake in which five bridges collapsed and 42 others were damaged significantly.

As part of the National Earthquake Hazards Reduction Program, NBS conducts research and provides technical support to the private sector and government agencies which are working to improve the performance of buildings and other structures subjected to earthquakes.

Last month, NBS researchers completed a series of laboratory tests on full-scale, reinforced concrete bridge columns under simulated earthquake conditions. This work, partially sponsored by the California Department of Transportation, will help determine the effectiveness of current California design criteria. It also will be used to determine whether small-scale tests and computer models can accurately predict seismic performance of fullscale bridge structures.

NBS also is conducting laboratory studies on the performance of reinforced concrete masonry under earthquake loadings. In addition, Lew and his staff are conducting research on strengthening methods for reinforced concrete structures.

NBS does not issue or enforce standards or regulations. The results of Bureau research will go to groups that do set and enforce such standards and regulations and will provide the basis for safer, more economical design practices.

Lyons said that although this earthquake was modest, it cost three lives directly and more than $\$ 200$ million in property damages. "It is a warning of the importance of the earthquake threat to the United States," he concluded.

For further information, contact $\mathrm{H}$. S. Lew at the National Bureau of Standards, Gaithersburg, MD 20899.

\section{NBS/GCA JOINT PROGRAM ON} "MOLECULAR MEASUREMENT MACHINE" NBS and GCA Corporation of Andover, Massachusetts, have begun a joint research program in support of an NBS project to develop a prototype measuring machine that will be capable of measuring surface features over an area approximately 5 centimeters square with a resolution of a single atom. The "Molecular Measurement Machine," under design by the NBS, will make use of extremely high-resolution probes, such as a tunneling microscope probe or atomic force probe, and will be able to make surface roughness measurements accurate to a tenth of an angstrom. Stanley Stone of GCA will work with NBS on the design and development of the machine structure, slideways, motor drives, interferometers, and associated control system needed for this new generation of measurement machines.

For further information, contact Clayton Teague at the National Bureau of Standards, Gaithersburg, MD 20899.

\section{POLYMER COMPOSITE PROCESSING RESEARCH NEEDS IDENTIFIED}

Two dozen companies met at NBS October 7 to address processing methods and barriers for polymer composites. These composites now are used in defense and specialty products, but other markets are expected to open up if processing methods can be improved.

The session at NBS, which was cochaired by representatives from Ford and NBS, identified a variety of scientific and engineering needs for improved processing methods which are expected to be of most interest to industry during the next 10 to 15 years. This information will be used to develop specific projects at NBS to aid industry in developing and applying these innovative materials.

NBS plans to pursue cooperative projects with industry where appropriate. A report on the workshop will be available in several months.

For further information, contact Donald Hunston at the National Bureau of Standards, Gaithersburg, MD 20899.

\section{NBS PROPOSES FEDERAL STANDARD \\ FOR OSI}

NBS is asking for comments on a proposed Federal Information Processing Standard (FIPS) which adopts the Government Open Systems Interconnection Profile (GOSIP). (FIPS are developed by NBS for use by the Federal government.)

GOSIP defines a common set of data communication protocols which enables computer systems 
developed by different vendors to communicate and allows the users of different applications on these systems to exchange information. It was developed by the Government OSI Users Committee, a group of Federal government agencies. GOSIP adopts international standards which enable information processing devices to communicate with one another in a network. GOSIP is based on agreements reached by vendors and computer users in NBS-sponsored workshops.

For a copy, contact Standards Processing Coordinator (ADP), Institute for Computer Sciences and Technology, B64 Technology Building, National Bureau of Standards, Gaithersburg, MD 20899 , or call 301/975-2816.

Comments on the proposed Federal standard should be sent to Director, Institute for Computer Sciences and Technology, Attn: GOSIP, B154 Technology Building, at the above address.

For technical information, contact Gerard F. Mulvenna, B217 Technology Building, National Bureau of Standards, Gaithersburg, MD 20899, or call 301/975-3631.

\section{MEASURING FAULTS IN PARALLEL PROCESSORS}

In a recent study for the Defense Advanced Research Projects Agency, NBS researchers investigated a number of measurement techniques that can be used to detect and recover from hardware faults in parallel processors.

"Fault-tolerance" is particularly important in computer systems used, for example, to solve large problems such as weather forecasting and to control aircraft and spacecraft. The researchers looked at ways to detect transmission and data storage errors and faults in processors, controllers, computer components, and input/output systems.

A report, On the Measurement of Fault-Tolerant Parallel Processors (NBSIR 87-3568), is available from the National Technical Information Service, Springfield, VA 22161 for $\$ 11.95$ prepaid. Order by $\mathrm{PB} \# 87-208328 / \mathrm{AS}$.

This work is part of an ongoing research effort to develop techniques and tools to measure the performance of parallel processors.

\section{RESEARCH DETECTS NUCLEAR REACTOR BURN-UP OF USSR CRAFT}

A study that examines the 1983 burn-up of a nuclear reactor from the Soviet reconnaissance satellite Cosmos-1402 is the subject of a just-published report. The satellite reactor, which normally would have been boosted into a long-lived orbit, fell into the Earth's atmosphere and disintegrated because of a malfunction.
To examine this event more closely, researchers from the Department of Energy's Environmental Measurements Laboratory (EML) collaborated with NBS scientists to identify reactor particles by analyzing stratospheric filter samples for their ratio of the radioactive isotopes uranium 235 and 238 . The project was undertaken because officials from EML - which investigates radioactive injections into the stratosphere-suspected that the reactor burn-up had occurred but had no direct evidence.

The team analyzed atmospheric samples in the NBS inorganic mass spectrometry laboratory, a custom facility well-suited for determining isotopic ratios. The samples, which were collected by special balloons at altitudes of 16 to 23 miles (27 to 39 kilometers), indicated large excesses of U-235. The researchers say this appears to indicate that the reactor did burn up in the stratosphere and that radioactive particles from the event will continue to spread out and dilute, posing no danger on Earth.

The research team's report is in the October 23, 1987, issue of Science.

\section{NBS REPORTS CAUSE OF FATAL BUILDING COLLAPSE}

The failure of a key component of the system for lifting concrete floor slabs in the L'Ambiance Plaza apartment building was the most probable cause for the building's April 23, 1987, collapse, said Charles Culver, chief of the NBS Structures Division, at a press briefing on October 22 .

Specifically, the collapse probably began when a jack rod supporting three concrete floor slabs slipped out of a U-shaped opening in a steel bracket. NBS researchers pinpointed the location where the jacking system used to lift the slabs into final position most likely failed. They investigated a variety of possible causes of failure, but concluded that only the lifting system failure played a significant role in initiating the collapse in which 28 construction workers died.

NBS was asked by the U.S. Occupational Safety and Health Administration to determine the cause of the collapse.

For information on ordering the NBS report, Investigation of L'Ambiance Plaza Building Collapse in Bridgeport, Connecticut (NBSIR 87-3640), contact the Structures Division, B268 Building Research Building, National Bureau of Standards, Gaithersburg, MD 20899, or call 301/975-6048.

\section{GOOD ATRIUM DESIGN CAN SAVE ENERGY}

Atrium spaces using large amounts of glass to let in daylight are aesthetic. But are they energy efficient? 
Using computer-simulation to evaluate atrium design in eight areas of the United States, NBS researchers found that savings ranging from about five percent in the Madison, Wisconsin, area up to 20 percent in Los Angeles are possible. However, total energy usage for areas like Madison were greater, so the actual dollar savings may be similar.

The researchers looked at several atrium designs and the effects of a variety of options such as solar shading, heat storage, and single- and double-pane glazings. The best-performing options seem to be the double-pane glazing combined with heat storage, but double-pane glazing alone also did well. Single-pane glazing is not effective, particularly in cold climates, and, surprisingly, say the researchers, the solar shading was not beneficial.

A report, Fenestration Design for Building Atria (NBSIR 87-3594), can be ordered for $\$ 13.95$ prepaid from the National Technical Information Service, Springfield, VA 22161. Order by title and PB \#87-171427.

\section{NEW WAY TO TEST SETTING TIME, STRENGTH OF CONCRETE}

NBS researchers are experimenting with a new test method for measuring the setting time and strength of concrete. The technique, called "impact-echo," uses sound waves and originally was developed by NBS researchers to detect flaws in concrete.

Currently, no standard field or laboratory test is available for measuring the setting time of concrete which may not accurately reflect environmental conditions at the site.

With the impact-echo method, the increase in the speed of sound through concrete is measured and correlated with setting time and subsequent strength development of the concrete.

A report on the method, Measurement of the Setting Time and Strength of Concrete by the ImpactEcho Method (NBSIR 87-3575), is available from the National Technical Information Service, Springfield, VA 22161 , for $\$ 18.95$ prepaid. Order by PB \#88-111851.

\section{Standard Reference Materials}

\section{IMPROVING N-PAH MEASUREMENTS IS AIM OF NEW MATERIAL}

Analytical laboratories that measure environmental samples for their concentration of certain nitrated polycyclic aromatic hydrocarbons (N-PAHs) will find a new NBS standard primarily for use in calibrating the chromatographic instruments used to measure these compounds. The new SRM, besides functioning as a calibration tool, also can be used to "spike" laboratory samples with known amounts of N-PAHs for research purposes.

The SRM has certified concentrations of four $\mathrm{N}$ PAH compounds-1-nitropyrene, 1,3-dinitropyrene, 1,6-dinitropyrene, and 1,8-dinitropyrene-in a solution of methylene chloride. Packaged in a kit containing five vials of the certified solution, the new material, Dinitropyrene Isomers and 1-Nitropyrene in Methylene Chloride (SRM 1596), is available for $\$ 281$.

\section{NBS, E. FJELD CO. PROGRAM ON SUBMICROMETER LINE STANDARDS}

The E. Fjeld Company of North Billerica, Massachusetts, a manufacturer of custom apparatus for scanning electron microscopes (SEMs), has started a joint program with the NBS to aid in the development of the next generation of NBS measurement standards for integrated circuit (IC) manufacturers.

E. Fjeld will work with NBS on combining a diamond turning instrument with an SEM for inprocess viewing of machining and on the design and development of a special SEM stage linked to a laser interferometer. These instruments will be used for the precision fabrication and measurement of typical IC structures with dimensions below one micrometer on opaque substrates. Such structures may be the basis for a new series of NBS standard reference materials for the measurement of submicrometer IC structures.

\section{NBS Services}

\section{NBS, NSA SETTING UP RISK MANAGEMENT LABORATORY}

NBS and the National Security Agency's National Computer Security Center are planning to establish a risk management research laboratory at NBS headquarters in Gaithersburg, MD. Risk management involves analyzing information assets, threats, and vulnerabilities; determining a measure of risk; then selecting cost-effective safeguards for reducing that risk.

The laboratory will be used to conduct research and provide the tools, techniques, and guidance needed to conduct this process. Other planned uses 
include helping Federal agencies select and use commercial risk management software and providing a clearinghouse for information on risk analysis and management for the Federal government.

For further information, contact Dennis Steinauer, B266 Technology Building, National Bureau of Standards, Gaithersburg, MD 20899, or call 301/975-3357.

\section{NBS ANNOUNCES ACCREDITATION \\ PROGRAM FOR LABORATORIES \\ TESTING ASBESTOS IN SCHOOLS}

An accreditation program for laboratories that test for asbestos in schools has been established by NBS under the National Voluntary Laboratory Accreditation Program (NVLAP) to meet the requirements of the Asbestos Hazard Emergency Response Act of 1986. The law requires the Environmental Protection Agency (EPA) to develop a program for the inspection, management, and abatement of asbestos in the nation's schools.

Under the law, NBS will accredit laboratories that perform analysis for asbestos content in samples of bulk insulation and building materials, and analyze airborne particulates collected during school inspections and asbestos abatement projects. The evaluation of laboratories that apply for asbestos bulk testing will commence about October 1988 . The first group of laboratories to be evaluated for accreditation will be those applying by December 28,1987 . Those applying after that date will be evaluated on a first-come first-served basis.

Accreditation for testing for airborne asbestos will begin in mid-1989.

For information on the new asbestos program, contact: Harvey W. Berger, Manager, National Voluntary Laboratory Accreditation Program, A531 Administration Building, National Bureau of Standards, Gaithersburg, MD 20899, or call 301/975-4016. 